\title{
Transformation of phenolic hydroxyl into acyl group: a new tool in organic synthesis
}

\author{
Antigoni Kotali \\ Laboratory of Organic Chemistry, College of Engineering, University of Thessaloniki, \\ Thessaloniki, GR-54006, Greece \\ E-mail: kotali@eng.auth.gr
}

\begin{abstract}
The progress that has been made in organic synthesis via the transformation of a phenolic hydroxyl into the acyl group is presented in this review. This transformation involves the formation of a new C-C bond.
\end{abstract}

Keywords: Transformation, phenol, hydroxyl, acyl group, formation of C-C bond

\section{Table of Contents}

1. Introduction

2. Transformation of Phenolic Hydroxyl into Carbonyl Group

2.1. Cyclisation reactions of $o$ - unsubstituted arylketone $\mathrm{N}$-acylhydrazones

2.2. Transformation reactions of $o$-hydroxy arylketone $N$-acylhydrazones. The initial reaction. Synthesis of 1,2-diacylbenzenes

3. The Mechanism

4. The Transformation of Hydroxyl into Carbonyl Group in Benzene Derivatives via Lead Tetraacetate Oxidation

5. The Transformation of Hydroxyl into Carbonyl Group in Heterocycles

6. Limitations

7. The Transformation of Hydroxyl into Carbonyl Group via Phenyliodoso Diacetate Oxidation

8. The Transformation of Hydroxyl into a Carbonyl Group via Sodium Oxidation

9. Conclusions 


\section{Introduction}

Interconversion of functional groups has always played an important role in organic synthesis. There have been many developments in the last decade regarding this area and two excellent editions "Comprehensive Organic Functional Group Transformations I" and recently "Comprehensive Organic Functional Group Transformations II" have presented the vast subject of organic synthesis in terms of the introduction and interconversion of all known functional groups, providing thus a unique information source documenting all methods of efficiently performing a particular transformation. ${ }^{1,2}$

During recent years our research has been focused on an unexpected new transformation of phenolic hydroxyl to a carbonyl group that we first found ${ }^{3}$ in our laboratory in 1987 . This transformation involves oxidation of $o$-hydroxy aryl ketones with lead tetraacetate (LTA) and allows the preparation of carbonyl compounds, formally unavailable, in high yields and in an easy experimental way.

The purpose of this review is to present all the findings regarding the transformation of phenolic hydroxyl into an acyl group as well as the progress that has been made in organic synthesis based on this transformation. The presentation will begin with a discussion of the substrates and the oxidants that have been used as well as of the suggested mechanism. The papers dealing with the oxidation of aryl ketones which are not substituted at ortho-position as well as of $o$-amino aryl ketones will also be covered. Finally, some of the applications and the importance of the derived products will be presented. It is hoped that this review will demonstrate the synthetic potential of the above transformation and generate some new ideas in this area.

\section{Transformation of Phenolic Hydroxyl into Carbonyl Group}

\subsection{Cyclisation reactions of $\boldsymbol{o}$-unsubstituted arylketone $\boldsymbol{N}$-acylhydrazones}

It has been known $^{4-7}$ since 1966 that $N$-acylhydrazones of aryl ketones $\mathbf{1}$ which are not substituted at the ortho-position readily undergo cyclization to 1,3,4-oxadiazolines 2 , which yield epoxides 3 with elimination of nitrogen on heating. Further heating at higher temperature leads to acetates 4. A characteristic example is given in Scheme 1.

In 1986, Alexandrou et al. reported $^{8}$ that the oxidation of bis-aroylhydrazones of isophthalaldehyde and terephthalaldehyde with LTA afforded the oxadiazoles 6 and 8 in 3095\%, as shown in Scheme 2. 


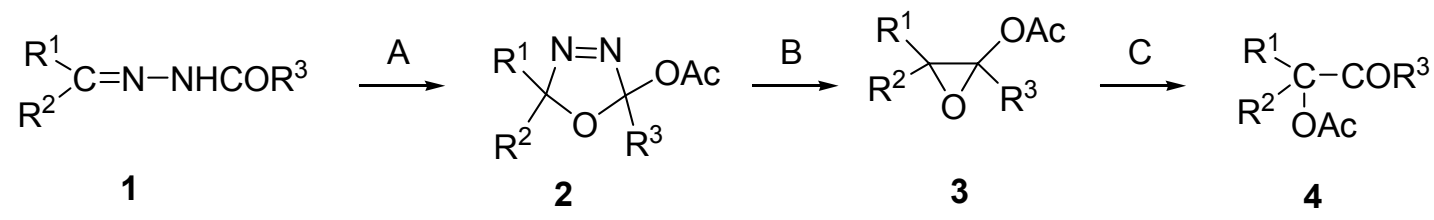
A: $\mathrm{Pb}(\mathrm{OAc})_{4} / \mathrm{CH}_{2} \mathrm{Cl}_{2} /-15$ to- $50^{\circ} \mathrm{C} / 44-75 \%$
B: $0-50^{\circ} \mathrm{C} / \mathrm{CCl}_{4} / 44-65 \%$
C: $170^{\circ} \mathrm{C} / 96-98 \%$

a: $R^{1}=P h, R^{2}=M e, R^{3}=P h ; b: R^{1}=R^{2}=P h, R^{3}=P h ; c: R^{1}-R^{2}=\left(C_{2}\right)_{5}, R^{3}=P h ; d: R^{1}=R^{2}=E t \quad R^{3}=P h$

B: $\mathrm{Pb}(\mathrm{OAc})_{4} / \mathrm{CH}_{2} \mathrm{Cl}_{2} /$ r.t./31-61\%

e: $R^{1}=R^{2}=M e, R^{3}=C_{2} P h ; f: R^{1}=R^{2}=M e, R^{3}=p-M e O C_{6} H_{4} C H_{2} ; g: R^{1}=R^{2}=M e, R^{3}=p-O_{2} N_{6} H_{4} C H_{2}$

Scheme 1. LTA oxidation of $N$-carbonylhydrazones of $o$-unsubstituted arylketones. ${ }^{4-7}$

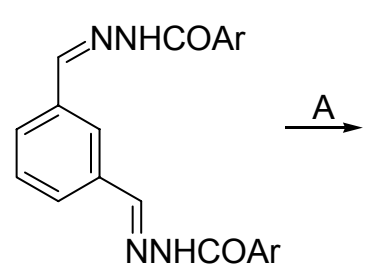

5<smiles>Brc1nnc(-c2cccc(-c3nnc(Br)o3)c2)o1</smiles>

$6(30-65 \%)$
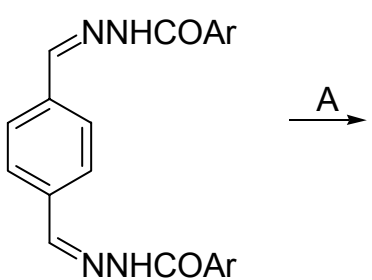

7<smiles>Brc1nnc(-c2ccc(-c3nnc(Br)o3)cc2)o1</smiles>

$8(40-95 \%)$

$\mathrm{A}: \mathrm{Pb}(\mathrm{OAc})_{4} / \mathrm{CHCl}_{3} / 25^{\circ} \mathrm{C} /$ or $\mathrm{AcOH} /$ reflux

$\mathrm{a}: \mathrm{Ar}=\mathrm{Ph} ; \mathrm{b}: \mathrm{Ar}=p-\mathrm{MeC}_{6} \mathrm{H}_{4} ; \mathrm{c}: \mathrm{Ar}=p-\mathrm{MeOC}_{6} \mathrm{H}_{4} ; \mathrm{d}: \mathrm{Ar}=p-\mathrm{ClC}_{6} \mathrm{H}_{4} ; \mathrm{e}: \mathrm{Ar}=p-\mathrm{O}_{2} \mathrm{NC}_{6} \mathrm{H}_{4}$

Scheme 2. Formation of di(oxadiazolyl)benzenes. ${ }^{8}$

2.2. Transformation reactions of $o$-hydroxy arylketone $N$-acylhydrazones. The initial reaction. Synthesis of 1,2-diacylbenzenes

It was in 1987 when we attempted to cyclize $N$-acylhydrazones of $o$-hydroxy aryl ketones $\mathbf{1 0}$ to 1,2-benzisoxazole $N$-imines $\mathbf{1 1}$ by treatment with lead tetraacetate. ${ }^{3}$

$o$-Hydroxyarylketones are very interesting molecules both because of their potential to serve as starting materials in organic synthesis as well as because of their applications. ${ }^{9}$ The presence 
of a hydroxyl and a carbonyl group at ortho positions to each other at the benzene ring allows the formation of novel heterocycles as well as other non-heterocyclic aromatic compounds. ${ }^{9}$

Furthermore, it is well known that lead tetraacetate reactions of hydrazones of carbonyl compounds lead to a variety of synthetically useful products. ${ }^{10}$

Thus, we thought that the hydroxyl group could interact with the hydrazone moiety to lead to the formation of 1,2-benzisoxazole $N$-imines 11. However, we found that monoacylhydrazones of type $\mathbf{1 0}$ do not yield $N$-imines $\mathbf{1 1}$ or the corresponding 1,3,4-oxadiazolines that would be formed if the reaction proceeded according to the literature data ${ }^{4-7}$ about the unsubstituted hydrazones (Scheme 1), but instead they undergo a rearrangement resulting in "replacement" of the phenolic hydroxyl with an acyl substituent to give ${ }^{3}$ 1,2-diacylbenzenes $\mathbf{1 2}$, in excellent yields $70-90 \%$, Scheme 3.

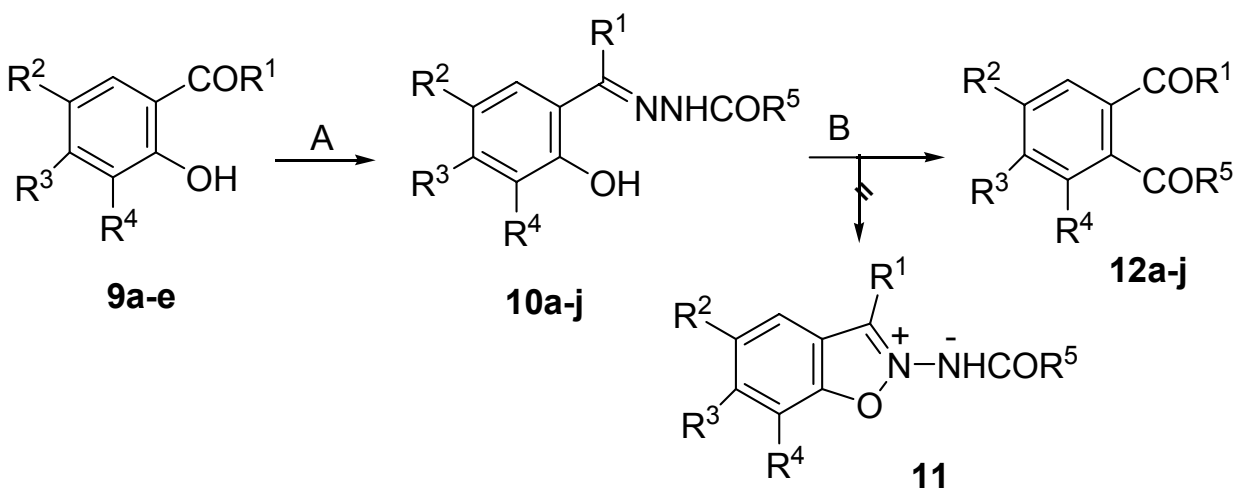

A: $\mathrm{R}^{5} \mathrm{CONHNH}_{2}$ /propanol/reflux, 24h/65-91\%

$\mathrm{B}: \mathrm{Pb}(\mathrm{OAc})_{4} / \mathrm{THF} / 25^{\circ} \mathrm{C}, 2 \mathrm{~h} / 68-95 \%$

9: $a: R^{1}=M e, R^{2}=R^{3}=R^{4}=H ; b: R^{1}=M e, R^{2}=H, R^{3}=O M e, R^{4}=H$;

C: $R^{1}=M e, R^{2}=B r, R^{3}=H, R^{4}=B r ; d: R^{1}=P h R^{2}=R^{3}=R^{4}=H$

e: $\mathrm{R}^{1}=\mathrm{Ph} \mathrm{R}^{2}=\mathrm{H}, \mathrm{R}^{3}=\mathrm{OMe}, \mathrm{R}^{4}=\mathrm{H}$

10,12: $a: R^{1}=M e, R^{2}=R^{3}=R^{4}=H, R^{5}=M e ; b: R^{1}=M e, R^{2}=R^{3}=R^{4}=H, R^{5}=P h$

c: $R^{1}=R^{2}=M e, R^{3}=R^{4}=H, R^{5}=P h ; d: R^{1}=M e, R^{2}=R^{4}=H, R^{3}=O M e, R^{5}=P h$

e: $R^{1}=M e, R^{2}=R^{4}=B r, R^{3}=H, R^{5}=P h ; f: R^{1}=M e, R^{2}=R^{3}=R^{4}=H, R^{5}=p-O_{2} N_{6} H_{4}$

g: $\mathrm{R}^{1}=\mathrm{Me}, \mathrm{R}^{2}=\mathrm{R}^{3}=\mathrm{R}^{4}=\mathrm{H}, \mathrm{R}^{5}=4$-pyridyl; $\mathrm{h}: \mathrm{R}^{1}=\mathrm{Ph} \mathrm{R}^{2}=\mathrm{R}^{3}=\mathrm{R}^{4}=\mathrm{H} \mathrm{R}^{5}=4$-pyridyl

i: $R^{1}=P h, R^{2}=R^{3}=R^{4}=H, R^{5}=P h ; j: R^{1}=P h R^{2}=R^{4}=H, R^{3}=O M e, R^{5}=P h$

Scheme 3. Synthesis of 1,2-diacylbenzenes. ${ }^{3}$

$o$-Diacylbenzenes have been of interest primarily as fluorescence reagents for both qualitative and quantitative high sensitivity analyses for amines and amino acids. ${ }^{11}$ Having the two acyl substituents at ortho-positions they could also serve as precursors in the synthesis of several heterocycles. However, there were no general methods for their synthesis and only in isolated cases they have been prepared in many steps and low yields. ${ }^{12}$ 


\section{The Mechanism}

Since no analogous transformations had been previously reported, the mechanism of this novel reaction was investigated. ${ }^{13}$ Crossover experiments demonstrated that the reaction is intramolecular. Furthermore, treatment of $o$-hydroxyacetophenone benzoyl- ${ }^{18} \mathrm{O}$-hydrazone $\mathbf{1 3}$ with LTA resulted in incorporation of ${ }^{18} \mathrm{O}$ at the acetyl position of the labeled 2acetylbenzophenone 14 (Scheme 4).<smiles>CC(=N)c1ccccc1O</smiles>

13<smiles>CC(=O)c1ccccc1C(=O)c1ccccc1</smiles>

14

$\mathrm{A}: \mathrm{Pb}(\mathrm{OAc})_{4} / \mathrm{THF} / 25^{\circ} \mathrm{C}, 2 \mathrm{~h} / 68-98 \%$

Scheme 4. Synthesis of labeled 2-acetylbenzophenone. ${ }^{13}$

Based on this oxygen-labeling evidence we have suggested a possible reaction mechanism that is presented in Scheme 5.

Thus, the formation of the expected organolead intermediate 15, followed by acetoxy migration to the hydrazone carbon gives initially azoacetate $\mathbf{1 6}$ and subsequently 1,3,4oxadiazoline 17. Intermediate $\mathbf{1 7}$ is indeed the final product obtained ${ }^{4-7}$ by LTA reactions with $o$-unsubstituted $\mathrm{N}$-acylhydrazones as hydrazones 1 in Scheme 1 . The presence of the hydroxy group seems to be crucial to the mechanism of the reaction. And at this stage we suggested that the $o$-hydroxyl group reacts with the oxadiazoline to give the 1,3-dioxane species $\mathbf{1 8}$. Elimination of nitrogen leads to the formation of epoxide 19, which can undergo electrocyclic rearrangement to form 1,2-diacylbenzene $\mathbf{1 2}$. 
<smiles>[R]C(=N)c1ccccc1O[Na]</smiles>

10

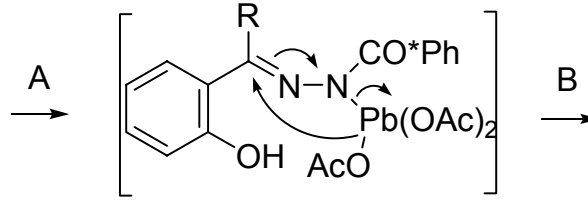

15<smiles>[R]C(O)(N=NC(=O)OCC)c1cccc(C)c1</smiles>

16

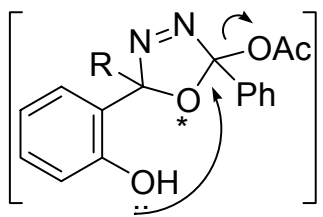

17

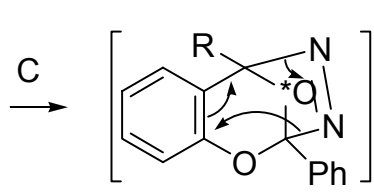

18

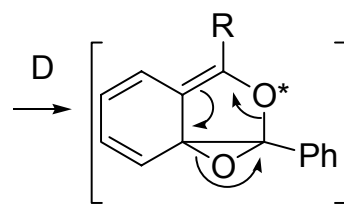

19<smiles>[R]Oc1ccccc1C(=O)Oc1ccccc1</smiles>

12

$\mathrm{A}: \mathrm{Pb}(\mathrm{OAc})_{4} /-\mathrm{AcOH} ; \mathrm{B}:-\mathrm{Pb}(\mathrm{OAc})_{2} ; \mathrm{C}:-\mathrm{AcOH} ; \mathrm{D}:-\mathrm{N}_{2}$

Scheme 5. Mechanism of the transformation of hydroxyl into a carbonyl group. ${ }^{13}$

\section{The Transformation of Hydroxyl into a Carbonyl Group in Benzene Derivatives via Lead Tetraacetate Oxidation}

The reaction was further applied to $N$-ethoxycarbonyl hydrazones $\mathbf{2 0}$ and $\mathbf{2 3}$ which led to the synthesis of a series of $o$-acylarylcarboxylic esters $\mathbf{2 1}$ and $\mathbf{2 4}$ in good yields. ${ }^{14}$ The results are presented in Schemes 6 and 7. The simplicity of the experimental procedure gives this reaction a considerable synthetic value. Moreover, classical methods to approach such structures often result in ring-closed pthalan derivatives. ${ }^{15}$<smiles>[R]C(=O)c1cc([R])c([R])c([R])c1O</smiles>

9

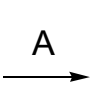<smiles>[R]C(=N)c1cc([R])c([R])c([R])c1O</smiles>

20<smiles>[R]Cc1cc([R])c([R])c([R])c1C(=O)O[R7]</smiles>

21

A: $\mathrm{R}^{5} \mathrm{CO}_{2} \mathrm{NHNH}_{2} /$ ethanol $/ 25^{\circ} \mathrm{C}, 24 \mathrm{~h} / 75-98 \%$

$\mathrm{B}: \mathrm{Pb}(\mathrm{OAc})_{4} / \mathrm{THF} / 25^{\circ} \mathrm{C} / 2 \mathrm{~h} / 60-90 \%$

21: a: $R^{1}=$ Me, $R^{2}=R^{3}=R^{4}=H, R^{5}=E t ; \quad b: R^{1}=M e, R^{2}=R^{3}=O M e, R^{4}=H, R^{5}=E t ; \quad c: R^{1}=E t$, $\mathrm{R}^{2}=\mathrm{R}^{3}=\mathrm{R}^{4}=\mathrm{H}, \mathrm{R}^{5}=\mathrm{Et} ; \mathrm{d}: \mathrm{R}^{1}=\mathrm{Ph}, \mathrm{R}^{2}=\mathrm{OMe}, \mathrm{R}^{3}=\mathrm{R}^{4}=\mathrm{H}, \mathrm{R}^{5}=\mathrm{Et} ; \quad \mathrm{e}: \mathrm{R}^{1}=\mathrm{R}^{2}=\mathrm{R}^{3}=\mathrm{R}^{4}=\mathrm{H}, \mathrm{R}^{5}=\mathrm{Et}$

Scheme 6. Transformation of phenolic hydroxyl to carboethoxylate. ${ }^{14}$ 
Extension of the rearrangement led to the synthesis of $o$-acylbenzaldehydes as shown in Scheme 8 . $N$-Formylhydrazones of $o$-hydroxyaryl ketones $\mathbf{2 5}$ as well as $N$-carbonylhydrazones of salicylaldehyde 27 both served as precursors to $o$-acylbenzaldehydes $28{ }^{16}$ Analogously, salicylaldehyde $N$-formylhydrazone 29 afforded phthalaldehyde 30 in 67\% yield, Scheme 9. Recently, Einhorn et al. applied this transformation to hydrazones 27, functionalized at the hydrazide aromatic moiety by nitro or iodo groups at any of the para, meta, or ortho positions to get the corresponding ketoaldehydes in good yields, 51-87\% and subsequently use them as precursors to an interesting regiospecific synthesis of functionalized 1,3-diarylisobenzofurans. ${ }^{17}$<smiles>[R]C(=O)c1cc([R])ccc1O</smiles>

9<smiles>[R]c1ccc(O)c(C=O)c1</smiles>

26

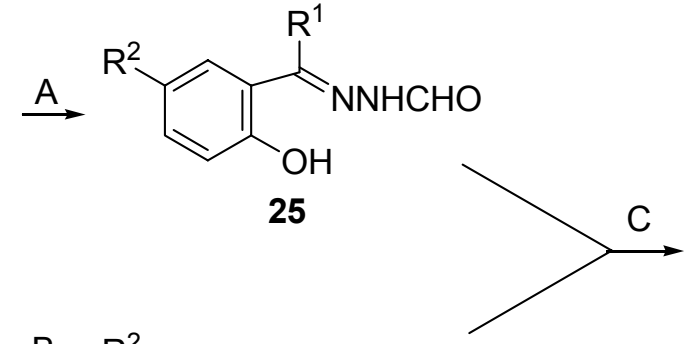<smiles>[R]CC(=O)N=Cc1cc([R]C)ccc1O</smiles>

27

A: $\mathrm{HCONHNH}_{2} /$ propanol/reflux/24h/68-87\%

B: $\mathrm{R}^{1} \mathrm{CONHNH}_{2} /$ propanol/reflux/24h/92-99\%

$\mathrm{C}: \mathrm{Pb}(\mathrm{OAc})_{4} / \mathrm{THF} / 25^{\circ} \mathrm{C}, 2 \mathrm{~h} / 77-82 \%$

a: $R^{1}=M e, R^{2}=H ; \quad b: R^{1}=E t, R^{2}=H ; \quad c: R^{1}=o-O H C_{6} H_{4}, R^{2}=H ; d: R^{1}=P h, R^{2}=M e ;$

e; $R^{1}=P h, R^{2}=H$

Scheme 8. Synthesis of $o$-acylbenzaldehydes. ${ }^{16}$

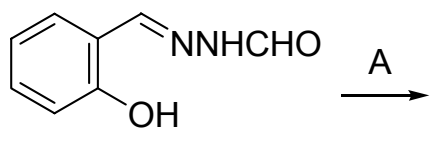

29<smiles>O=Cc1ccccc1C=O</smiles>

30

$\mathrm{A}: \mathrm{Pb}(\mathrm{OAc})_{4} / \mathrm{THF} / 25^{\circ} \mathrm{C}, 2 \mathrm{~h} / 67 \%$

Scheme 9. Synthesis of phtalaldehydes. ${ }^{16}$

Interestingly, the transformation of a phenolic hydroxyl to a carbonyl group was also successful when 5-bromo-2-hydroxybenzoyl bromide $N$-benzoylhydrazone $\mathbf{3 1}$ was treated with LTA. $^{14}$ The result was the formation of 5-bromo-2-benzoylbenzoyl bromide 32 in $75 \%$ yield, 
and the reaction is presented in Scheme 10. It is worthy to note that there is only one prior available preparative procedure for $o$-acylbenzoyl bromides. ${ }^{18}$<smiles>O=C(N=C(Br)c1cc(Br)ccc1O)c1ccccc1</smiles>

31<smiles>O=C(Oc1ccccc1)c1ccc(Br)cc1Br</smiles>

32

$\mathrm{A}: \mathrm{Pb}(\mathrm{OAc})_{4} / \mathrm{THF} / 25^{\circ} \mathrm{C}, 2 \mathrm{~h} / 75 \%$

Scheme 10. Synthesis of 5-bromo-2-benzoyl bromide. ${ }^{16}$

Our desire to further extend the unusual transformation which was found in our laboratories, led us to use ketones bearing two acyl groups and one hydroxyl ortho to each other, as starting substrate. ${ }^{19}$ Thus, the starting ketones $\mathbf{3 3}$ were initially treated with the appropriate hydrazide, in $1: 1$ ratio to give monohydrazones 34 either as a single isomer (when $\mathrm{R}^{1}=\mathrm{R}^{2}$ ) or as a mixture of two isomers 34 and $\mathbf{3 5}$ (when $\mathrm{R}^{1} \# \mathrm{R}^{2}$ ), Scheme 11. It was not necessary to separate the isomeric mixtures of $\mathbf{3 4}$ and $\mathbf{3 5}$ for the conversion to 36. LTA oxidation of the mixture afforded 1,2,3triacylbenzenes 36 in very good yields.

Later, this methodology was further extended to the preparation of 1,3-dibenzoyl-2,4diacetyl- and 1,5-dibenzoyl-2,4-diacetylbenzenes $\mathbf{4 2}$ and $\mathbf{4 3}$ in good yields, 73\% and 55\% respectively. ${ }^{20}$ The transformation is presented in Scheme 12.<smiles>[R]Oc1cc(C)cc(C(=O)O)c1O</smiles>

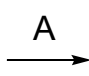

33

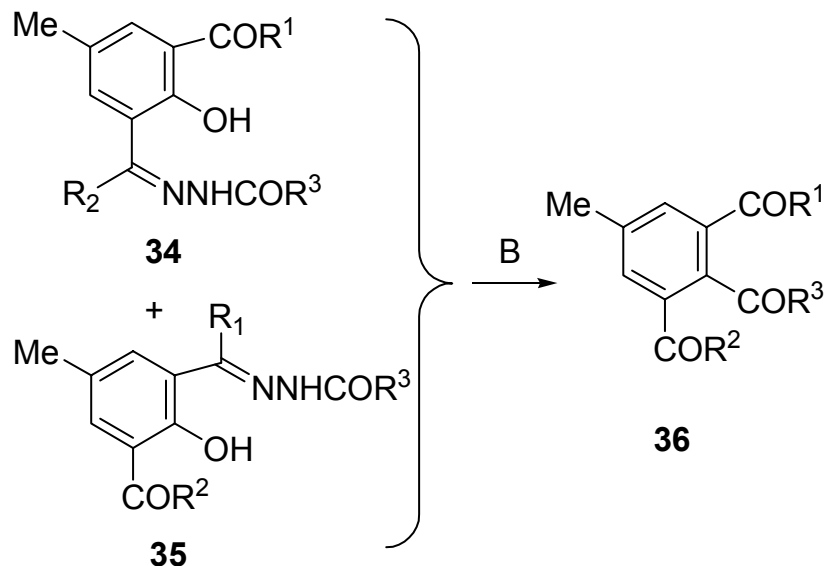

A: $\mathrm{R}^{3} \mathrm{CONHNH}_{2} /$ propanol/reflux, 24h/68-90\%

B: $\mathrm{Pb}(\mathrm{OAc})_{4} / \mathrm{THF} / 25^{\circ} \mathrm{C}, 2 \mathrm{~h} / 63-92 \%$

a: $\mathrm{R}^{1}=\mathrm{Me}, \mathrm{R}^{2}=\mathrm{Ph}, \mathrm{R}^{3}=\mathrm{Me} ; \mathrm{b}: \mathrm{R}^{1}=\mathrm{Me}, \mathrm{R}^{2}=\mathrm{Ph}, \mathrm{R}^{3}=4$-pyridyl; c: $\mathrm{R}^{1}=\mathrm{Me}, \mathrm{R}^{2}=\mathrm{Ph}, \mathrm{R}^{3}=p-\mathrm{NO}_{2} \mathrm{C}_{6} \mathrm{H}_{4}$;

d: $R^{1}=M e, R^{2}=R^{3}=P h ; e: R^{1}=R^{2}=R^{3}=P h ; f: R^{1}=R^{2}=P h, R^{3}=M e$

Scheme 11. Synthesis of 1,2,3-triacylbenzenes. ${ }^{19}$ 


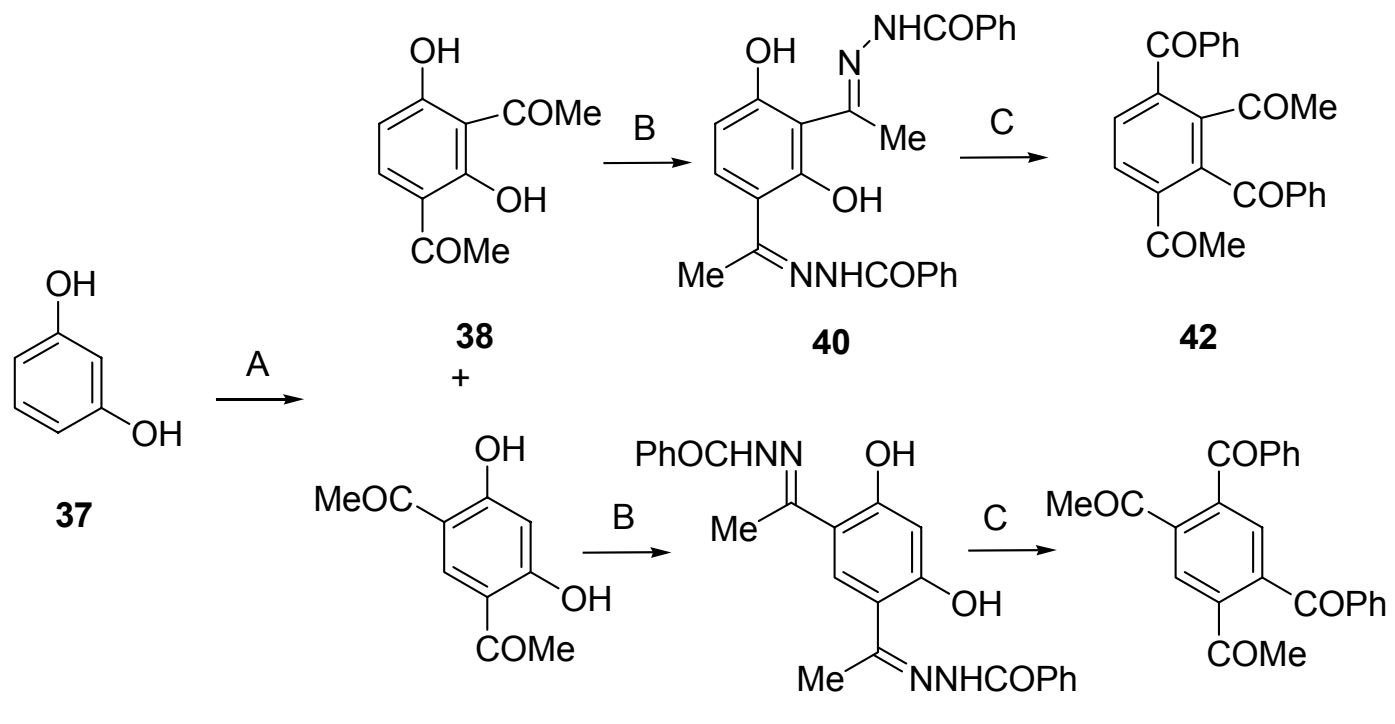
A: $\mathrm{AlCl}_{3} / \mathrm{MeCOCl} / 120^{\circ} \mathrm{C} / 2 \mathrm{~h} / 40 \%$ for $38,24 \%$ for 39
B: $\mathrm{PhCONHNH} / 2$ propanol/ reflux $/ 24 \mathrm{~h} / 88 \%$ for $\mathbf{4 0}, 82 \%$ for $\mathbf{4 1}$
C: $\mathrm{Pb}(\mathrm{OAc})_{4} / \mathrm{THF} / 25^{\circ} \mathrm{C} / 2 \mathrm{~h} / 73 \%$ for $\mathbf{4 2}, 55 \%$ for $\mathbf{4 3}$

Scheme 12. Synthesis of tetraacylbenzenes. ${ }^{20}$

In contrast with $N$-acylhydrazones of $o$-hydroxyaryl ketones, $o$-aminoaryl ketones $N$ acylhydrazones 45 underwent oxidative cyclization under treatment with LTA to give 2acylaminoindazoles 46 in very good yields, 60-80\%, Scheme $13 .{ }^{21}$<smiles>Nc1ccccc1C(=O)O</smiles>

44

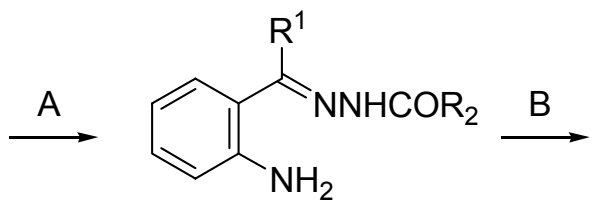

45<smiles>[R]C(=O)Nn1nc2ccccc2c1[R]</smiles>

46
A: $\mathrm{R}^{2} \mathrm{CONHNH}_{2} /$ propanol/reflux/ 69-95\%
$\mathrm{B}: \mathrm{Pb}(\mathrm{OAc})_{4} / \mathrm{THF} / 25^{\circ} \mathrm{C} / 2 \mathrm{~h} / 68-95 \%$
a: $\mathrm{R}^{1}=\mathrm{Me}, \mathrm{R}^{2}=\mathrm{Ph} ; \mathrm{b}: \mathrm{R}^{1}=\mathrm{Me}, \mathrm{R}^{2}=\mathrm{Me} ; \mathrm{c}: \mathrm{R}^{1}=\mathrm{Me}, \mathrm{R}^{2}=\mathrm{o}-\mathrm{HOC}_{6} \mathrm{H}_{4}$
d: $R^{1}=R^{2}=P h ;$ e: $R^{1}=$ Me, $R^{2}=$ OEt; $f: R^{1}=M e, R^{2}=O_{C H} P h$

Scheme 13. Oxidative cyclisation of $o$-aminoarylketone $N$-acylhydrazones. ${ }^{21}$

Having shown that $o$-hydroxyaryl ketones yield the LTA induced transformation whereas, aminoaryl ketones yield LTA cyclisation reactions, we examined which pathway would be 
followed if both functionalities were present. ${ }^{22}$ Thus, $N$-acylhydrazones of 2-amino-2'hydroxybenzophenone 48 were treated with LTA and afforded dibenz[b,e]azepin-11-ones 49, in overall satisfactory yields, Scheme 14 . We suggested that the reaction resulted to the hydroxyl replacement to give 2-acetyl- and 2-aroyl-2'-aminobenzophenone intermediates 50, which without isolation, readily underwent dehydrative cyclization to the dibenz $[b, e]$ azepin-11-ones $\mathbf{4 9}$, Scheme 15. Intermediates 50 were probably formed according to the findings of our earlier mechanistic study. ${ }^{9}$<smiles>Nc1ccccc1C(=O)c1ccccc1O</smiles>

47<smiles>[R]C(=O)NN=C(c1ccccc1N)c1ccccc1O</smiles>

48
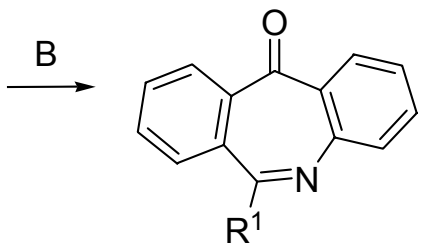

49

A: $\mathrm{R}^{1} \mathrm{CONHNH} \mathrm{N}_{2} /$ propanol/reflux, $24 \mathrm{~h} / 77-87 \%$

$\mathrm{B}: \mathrm{Pb}(\mathrm{OAc})_{4} / \mathrm{THF} / 25^{\circ} \mathrm{C} / 2 \mathrm{~h} / 38-74 \%$

a: $\mathrm{R}^{1}=\mathrm{Ph} ; \mathrm{b}: \mathrm{R}^{1}=0-\mathrm{HOC}_{6} \mathrm{H}_{4} ; \mathrm{c}: \mathrm{R}^{1}=0-\mathrm{O}_{2} \mathrm{NC}_{6} \mathrm{H}_{4} ; \mathrm{d}: \mathrm{R}^{1}=p-\mathrm{O}_{2} \mathrm{NC}_{6} \mathrm{H}_{4} ; \mathrm{e}: \mathrm{R}^{1}=\mathrm{Me}$

Scheme 14. Synhesis of 6-substituted dibenzazepin-11-ones. ${ }^{22}$

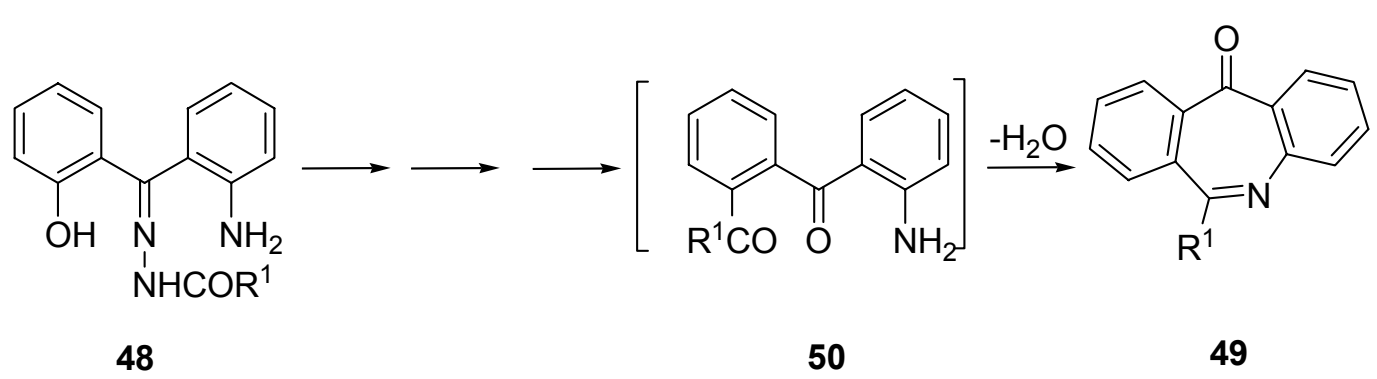

Scheme 15. Proposed mechanism for the LTA cyclisation of $o$-amino arylketones $N$-acylhydrazones. ${ }^{22}$

\section{The Transformation of Hydroxyl into a Carbonyl Group in Heterocycles}

Our continuous interest in the potentialities of the above "replacement" in organic synthesis led us to design the synthesis of 7,8-diacylcoumarins $\mathbf{5 3}$ applying this transformation in the coumarin substrate 51 that bears hydroxyl ana acetyl groups at ortho positions (Scheme 16). 7Hydroxy-8-acetylcoumarin $N$-acylhydrazones $\mathbf{5 2}$ were treated with LTA. The transformation of phenolic hydroxy to a carbonyl group worked out smoothly and 7,8-diacylcoumarins $\mathbf{5 3}$ were formed in very good yields, $73-90 \% .^{23,24}$ The transformation was also successfully applied to 7 - 
hydroxy-8-acetylcoumarin $N$-ethoxycarbonyl hydrazone $\mathbf{5 2 l}$ and led to the formation of the corresponding angular 8 -acetylcoumarin-7-ethoxycarboxylate 531. ${ }^{23}$<smiles>CC(=O)c1c(O)ccc2ccc(=O)oc12</smiles>

51<smiles>CC(=O)N=[NH+]C(C)c1c(O)ccc2ccc(=O)oc12</smiles>

52<smiles>[R]C(=O)c1ccc2ccc(=O)oc2c1C(C)=O</smiles>

53
A: $\mathrm{R}^{1} \mathrm{CONHNH} / 2$ propanol/reflux/24h/ 90-98\%
B: $\mathrm{Pb}(\mathrm{OAc})_{4} / \mathrm{THF} /$ r.t./2-24h/65-90\%
a: $\mathrm{R}^{1}=\mathrm{Ph} ; \mathrm{b}: \mathrm{R}^{1}=p-\mathrm{MeC}_{6} \mathrm{H}_{4} ; \quad$ c: $\mathrm{R}^{1}=p-\mathrm{HOC}_{6} \mathrm{H}_{4} ; \mathrm{d}: \mathrm{R}^{1}=0-\mathrm{HOC}_{6} \mathrm{H}_{4} ; \mathrm{e}: \mathrm{R}^{1}=0-\mathrm{O}_{2} \mathrm{NC}_{6} \mathrm{H}_{4}$
f: $\mathrm{R}^{1}=2^{\prime}$-furyl; g: $\mathrm{R}^{1}=2^{\prime}$-thienyl; $h: \mathrm{R}^{1}=p-\mathrm{O}_{2} \mathrm{NC}_{6} \mathrm{H}_{4} ; \mathrm{i}: \mathrm{R}^{1}=4^{\prime}-$ pyridyl; $\mathrm{j}: \mathrm{R}^{1}=\mathrm{CH}_{2} \mathrm{Ph}$
$\mathrm{k}: \mathrm{R}^{1}=\mathrm{Me} ; \mathrm{I}: \mathrm{R}^{1}=\mathrm{OEt}$

Scheme 16. Transformation of hydroxyl into a carbonyl group in coumarins. ${ }^{23,24}$

It is well known that coumarin is a biologically active compound and its derivatives have been extensively used for the treatment of a variety of diseases. ${ }^{25}$ Because the pharmacological and biochemical properties and therapeutic alterations in the structures of coumarins depend ${ }^{26}$ upon substitution pattern, we synthesized ${ }^{27}$ linear 6,7-diacylcoumarins $\mathbf{5 6}$ (Scheme 17).

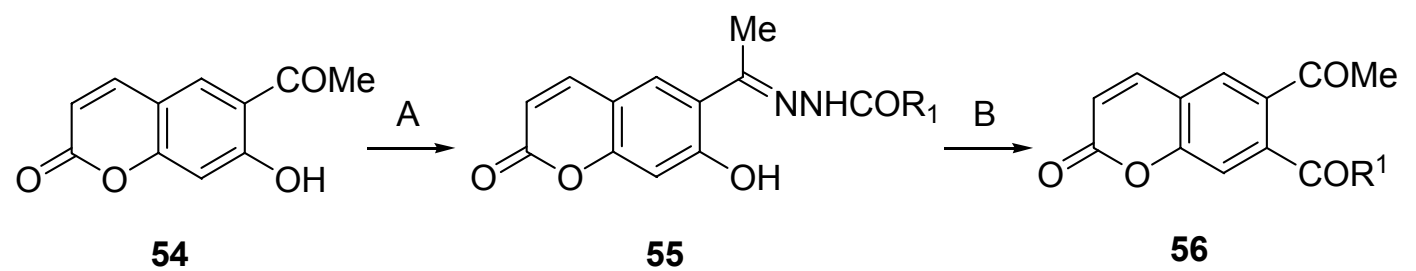
A: $\mathrm{R}^{1} \mathrm{CONHNH} / 2$ propanol/reflux/24h/75-92\%
B: $\mathrm{Pb}(\mathrm{OAc})_{4} / \mathrm{THF} /$ r.t./2-24h/60-73\%

a: $R^{1}=P h ; b: R^{1}=o-H O C_{6} H_{4} ; c: R^{1}=o-O_{2} N_{6} H_{4} ; \quad d: R^{1}=2^{\prime}$-furyl; e: $R^{1}=2^{\prime}$-thienyl; $f: R^{1}=M e$

Scheme 17. Synthesis of 6,7-diacylcoumarins. ${ }^{27}$

\section{Limitations}

Treatment of $o$-hydroxyphenyl-1-propenyl ketone benzoylhydrazone ${ }^{28} \mathbf{5 7}$ as well as the 1hydroxy-9H-fluoren-9-one benzoylhydrazone $\mathbf{5 8}$ led to very complicated mixtures. ${ }^{29}$ Both 
hydrazones 57 and 58 possess a double bond at the $\alpha$-carbon of hydrazonyl group that possibly influences the mechanism of the reaction.

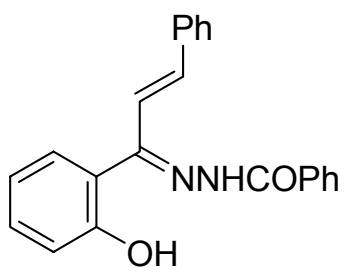

57<smiles>O=C(N=C1c2ccccc2-c2ccccc21)c1ccccc1</smiles>

58

Figure 1

\section{The Transformation of Hydroxyl into a Carbonyl Group via Phenyliodoso Diacetate Oxidation}

It is well known that phenyliodoso diacetate (PID) is a mild oxidizing agent and a very useful reagent in organic synthesis. It shows reactivity similar to LTA and it is less hazardous, and toxic than lead(IV)compounds. ${ }^{30}$ However, although it is a mild oxidizing agent it has been not so often used for oxidations of hydrazones. In 1986 it has been reported that the PID oxidation of aldehyde carbo-t-butoxyhydrazones 59 affords 5-substituted-1,3,4-oxadiazolin-2-ones $\mathbf{6 0}$ in good yields as shown in Scheme 18. ${ }^{31}$

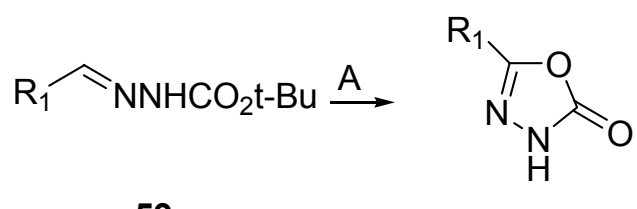

59

60
A: $\mathrm{Phl}(\mathrm{OAc})_{2} / \mathrm{MeOH} / \mathrm{reflux} / \mathrm{N}_{2} / 25-30 \mathrm{~min} / 47-67 \%$
a: $\mathrm{R}^{1}=\mathrm{Ph} ; \mathrm{b}: \mathrm{R}^{1}=4-$ pyridyl

Scheme 18. Cyclisation of aldehyde $N$-carbonylbutoxy hydrazones. ${ }^{31}$

In 1990 the initial transformation of hydroxyl into a carbonyl group which is shown in Scheme 3 was performed using phenyliodoso diacetate (PID) instead of LTA and results analogous to those with LTA were obtained. ${ }^{32}$ It was suggested that the mechanism of this reaction should be analogous to the LTA mechanism. ${ }^{32,9}$ Alternatively, cross-linked [polystyrene(iodoso diacetate)] has been successfully used as an oxidative agent. ${ }^{33}$ 
Later, PID was also successfully used as an alternative oxidative agent for the synthesis of several substituted $o$-ketoaryl esters ${ }^{34} \mathbf{2 1}$ from hydrazones 20, of tetraacylbenzenes ${ }^{20} \mathbf{4 2}$ and $\mathbf{4 3}$, of indazoles 46, of 7,8-diacylcoumarins ${ }^{24} \mathbf{5 3}$ as well as of 6-carbonylthienyl-7-acetyl-coumarin ${ }^{27}$ 56e. The transformation was successful and the yields were good and comparable with those obtained by the LTA oxidations. The products were isolated by column chromatography both in LTA and PID oxidations. In LTA oxidations of hydrazones 10, diacylbenzenes $\mathbf{1 2}$ were isolated by crystallisation from chloroform/petroleum ether (Table 1).

Table 1. Transformation of hydroxyl by a carbonyl group via phenyliodoso diacetate oxidation ${ }^{\mathrm{a}, \mathrm{b}}$

\begin{tabular}{|c|c|c|c|c|c|c|c|c|}
\hline Substrate & PID & oxidation & & & LTA & xidation & & \\
\hline Hydrazone & Product & $\begin{array}{c}\text { Yield } \\
\%\end{array}$ & Isolation & Ref. & Product & $\begin{array}{c}\text { Yields } \\
\%\end{array}$ & Isolation & Ref. \\
\hline $10^{\mathrm{a}}$ & $\begin{array}{c}\text { 12a-d, f, } \\
\text { k-o }\end{array}$ & $60-97$ & B & 32 & $12 a-j$ & $68-95$ & A & 3 \\
\hline $20^{\mathrm{b}}$ & $21 a-m^{d}$ & $68-95$ & B & 34 & 21a-e & $60-90$ & B & 14 \\
\hline $40^{b}$ & 42 & 68 & B & 20 & 42 & 73 & B & 20 \\
\hline $41^{\mathrm{b}}$ & 43 & 50 & B & 20 & 43 & 55 & B & 20 \\
\hline $45^{\mathrm{b}}$ & 46a-f & $55-79$ & B & 35 & 46a-f & $68-95$ & B & 21 \\
\hline $52^{b}$ & 53a-l & $62-90$ & B & 24 & 53a-l & $65-90$ & B & $\begin{array}{c}23,2 \\
4\end{array}$ \\
\hline $55^{\mathrm{b}}$ & $56 e$ & 60 & B & 27 & 56a-f & $60-73$ & $\mathrm{~B}$ & 27 \\
\hline
\end{tabular}

${ }^{a}$ Oxidation conditions: $\mathrm{Ph}\left[\mathrm{I}(\mathrm{OAc})_{2}\right] / \mathrm{CH}_{2} \mathrm{Cl}_{2} / 25^{\circ} \mathrm{C} / 0.33-44 \mathrm{~h} . \quad{ }^{\mathrm{b}}$ Oxidation conditions: $\mathrm{Ph}\left[\mathrm{I}(\mathrm{OAc})_{2}\right] / \mathrm{CH}_{2} \mathrm{Cl}_{2} / 25^{\circ} \mathrm{C} / 2 \mathrm{~h} . \quad{ }^{\mathrm{c}} \mathrm{k}: \quad \mathrm{R}^{1}=\mathrm{Me}, \quad \mathrm{R}^{2}=\mathrm{R}^{3}=\mathrm{R}^{4}=\mathrm{H}, \quad \mathrm{R}^{5}=\quad p-\mathrm{MeOC}_{6} \mathrm{H}_{4} ; \quad 1: \quad \mathrm{R}^{1}=\mathrm{Me}$ $\mathrm{R}^{2}=\mathrm{R}^{3}=\mathrm{R}^{4}=\mathrm{H}, \mathrm{R}^{5}=p-\mathrm{MeC}_{6} \mathrm{H}_{4} ; \mathrm{m}: \mathrm{R}^{1}=\mathrm{Me}, \mathrm{R}^{2}=\mathrm{R}^{3}=\mathrm{R}^{4}=\mathrm{H}, \mathrm{R}^{5}=2$-furyl; $\mathrm{n}: \mathrm{R}^{1}=\mathrm{Me}, \mathrm{R}^{2}=\mathrm{R}^{3}=\mathrm{R}^{4}=\mathrm{H}$, $\mathrm{R}^{5}=2$-thienyl; o: $\mathrm{R}^{1}=\mathrm{Et}, \mathrm{R}^{2}=\mathrm{R}^{3}=\mathrm{R}^{4}=\mathrm{R}^{5}=\mathrm{H} . \quad \mathrm{g}^{\mathrm{d}}: \mathrm{R}^{1}=\mathrm{R}^{2}=\mathrm{Me}, \mathrm{R}^{3}=\mathrm{H}, \mathrm{R}^{4}=\mathrm{Et} ; \quad \mathrm{h}: \mathrm{R}^{1}=\mathrm{R}^{2}=\mathrm{R}^{3}=\mathrm{Me}$, $\mathrm{R}^{4}=\mathrm{Et} ; \quad \mathrm{i}: \mathrm{R}^{1}=\mathrm{Me}, \mathrm{R}^{2}=\mathrm{Cl}, \mathrm{R}^{3}=\mathrm{H}, \mathrm{R}^{4}=\mathrm{Et} ; \mathrm{j}: \mathrm{R}^{1}=\mathrm{Me}, \mathrm{R}^{2}=\mathrm{Br}, \mathrm{R}^{3}=\mathrm{H}, \mathrm{R}^{4}=\mathrm{Et} ; \quad \mathrm{k}: \mathrm{R}^{1}=p-\mathrm{HOC}_{6} \mathrm{H}_{4}$, $\mathrm{R}^{2}=\mathrm{R}^{3}=\mathrm{H}, \mathrm{R}^{4}=\mathrm{Et} ; \mathrm{l}: \mathrm{R}^{1}=\mathrm{Me}, \mathrm{R}^{2}=\mathrm{R}^{3}=\mathrm{H}, \mathrm{R}^{4}=\mathrm{CH}_{2} \mathrm{Ph} ; \mathrm{m}: \mathrm{R}^{1}=\mathrm{Et}, \mathrm{R}^{2}=\mathrm{R}^{3}=\mathrm{H}, \mathrm{R}^{4}=\mathrm{CH}_{2} \mathrm{Ph}$.
A: Crystalisation by treatment with chloroform/pet. ether
B: Column chromatography

\section{The Transformation of Hydroxyl into a Carbonyl Group via Sodium Hypochlorite Oxidation}

Sodium hypochlorite is also a mild oxidizing agent and has the advantages of being less toxic and less costly. Treatment of $o$-hydroxyacetophenone $N$-benzoylhydrazone $10 \mathrm{~b}$ with sodium hypochlorite for two hours at room temperature led to the formation of 1-acetyl-2benzoylbenzene $\mathbf{1 2 b}$ in $52 \%$ yield. ${ }^{36}$ Thus, the transformation of phenolic hydroxy to an acyl 
group was successful. However, the generality of this reaction as well as the optimisation of the yield should be further investigated.

\section{Conclusions}

The transformation of a hydroxyl into an acyl group works smoothly in several carbocyclic and heterocyclic substrates and gives the ability for the synthesis of ortho-diacylsubstituted carbocyclic and heterocyclic compounds respectively which were previously unavailable. Despite the difficulties for their preparation, both $o$-acylbenzaldehydes ${ }^{37}$ or $o$-diacylbenzenes ${ }^{12}$ have been shown to be useful starting materials in the synthesis of various compounds such as 1,3-diarylisobenzofurans, isoindoles, phthalimidines, isoindoloquinazolines, indanes, naphthols, olefins and they could be promising tools in organic synthesis in the future. The products could further serve also as useful intermediates to the synthesis of various derivatives with possible pharmaceutical properties.

The simplicity of the experimental procedure, the generality, the high yields and the low cost of the reagents add to the synthetic value of the method.

\section{References}

1. Katritzky, A. R.; Taylor, R. J. K. Comprehensive Organic Functional Group Transformations I, Elsevier, Pergamon, UK, 1995.

2. Katritzky, A. R.; Taylor, R. J. K. Comprehensive Organic Functional Group Transformations II, Elsevier, Pergamon, UK, 2005.

3. Kotali, A.; Tsoungas, P. G. Tetrahedron Lett. 1987, 28, 4321.

4. Hoffmann, R. W.; Luthardt, H. J. Tetrahedron Lett. 1966, 4, 411.

5. Hoffmann, R. W.; Luthardt, H. J. Tetrahedron Lett. 1967, 36, 3501.

6. Hoffman, R. W.; Luthardt, H. J. Chem. Ber. 1968, 101, 3851.

7. Stephanidou-Stephanatou, J.; Lefkopoulou, S. J. Heterocycl. Chem. 1982, 19, 705.

8. Rekkas, S. A.; Rodios, N. A.; Alexandrou, N. E. Synthesis 1986, 5, 411.

9. Kotali, A.; Harris, P. A. Org. Prep. Proc. Int. 1994, 26, 155.

10. Kotali, A. Cur. Org. Chem. 2002, 26, 965.

11. (a) Weygand, F.; Weber, H.; Maekawa, E.; Eberhardt, G. Chem. Ber. 1956, 89, 1994. (b) Roth, M. Anal. Chem. 1971, 43, 880. (c) Sternson, L. A.; Stobaugh, J. F.; Repta, A. J. Anal. Biochem., 1985, 144, 233. (d) Beale, S. C.; Savage, J. C.; Wiesler, D.; Wietstock, S. M.; Novotny, M. Anal. Chem. 1988, 60, 1765.

12. Kotali, A., Harris, P. A. Org. Prep. Proc. Int. 2003, 35, 583.

13. Katritzky, A. R.; Kotali, A; Harris, P. A. J. Org. Chem. 1991, $56,5049$.

14. Katritzky, A. R.; Kotali, A. Tetrahedron Lett. 1990, 31, 6781. 
15. Tobia, D.; Rickborn, B. J. Org. Chem. 1986, 51, 3849.

16. Kotali, A; Dimos, V.; Papapetrou, M.; Harris, P. A. Org. Prep. Proc. Int. 1998, 30, 177.

17. Jacq, J.; Einhorn, C.; Einhorn, J. Org. Lett. 2008, 8, 1525.

18. Bains, S.; Green, J.; Tan, L. C.; Pagni, R. M.; Kabalka, G. W. Tetrahedron Lett. 1992, 33, 7475.

19. Kotali, A.; Glaveri, U.; Pavlidou,E.; Tsoungas,P. G. Synthesis 1990, 12, 1172.

20. Kotali, A. Tetrahedron Lett. 1994, 35, 6753.

21. Kotali, A; Harris, P. A. Heterocycles 1994, 37, 1541.

22. Kotali, A; Lazaridou, E.; Papageorgiou, V. P.; Harris, P. A. Heterocycles, 2001, 55, 1057.

23. Kotali, A.; Lafazanis, I. S.; Harris, P. A. Tetrahedron Lett. 2007, 48, 7181.

24. Kotali, A.; Lafazanis, I. S.; Harris, P. A. Synthesis 2008, 5, 836.

25. (a) Prince, M.; Campbell, C. T.; Robertson, T. A.; Wells, A. J.; Kleiner, H. E. Carcinogenesis 2006, 29, 1204. (b) Nam, N.-H.; Kim, Y.; You, Y.-J.; Hong, D.-H.; Ahn, B.-Z. Bioorg. Med. Chem. Lett. 2002, 12, 2345. (c) Kleiner, H. E.; Vulimiri, S.V.; Miller, L.; Johnson, W. H; Whitman, C.P.; DiGiovanni, J. Carcinogenesis 2001, 22, 73.

26. Kostova, I. Curr. Med. Chem.-Anti Cancer Agents 2005, 5, 29.

27. Kotali, A.; Lafazanis, I. S.; Harris, P. A. Synth. Comm. 2008, 38, 3996.

28. Kotali, A., Lafazanis, G. S. Molbank 2003, M349.

29. Kotali, A., unpublished results.

30. Criege, R. Oxidation in Organic Chemistry, Academic: New York, 1965, p365

31. Baumgarten, H. E., Hwang, D.-R., Rao, T. N. J. Heterocycl. Chem. 1986, 945.

32. Moriarty, R. M.; Berglund, B. A.; Rao, M. S. C. Synthesis 1993, 318.

33. Huang, X.; Zhu, Q. Synth. Commun. 2001, 31, 2413.

34. Kotali, A; Koulidis, A.; Harris, P. A.; Huey M. W.; Ling, C.C. Org. Prep. Proc. Int. 1996, $28,622$.

35. Kotali, A; Harris, P. A. J. Heterocycl. Chem. 1996, 33, 605.

36. Kotali, A., Lafazanis, G. S. Abstracts of 230th ACS National Meeting, August 28-September 1, 2005, Washington DC, USA, ORGN 77.

37. Kotali, A., Lafazanis, G. S., Christofidou, A. ARKIVOC 2003, (i), 56. 


\section{Author's biography}

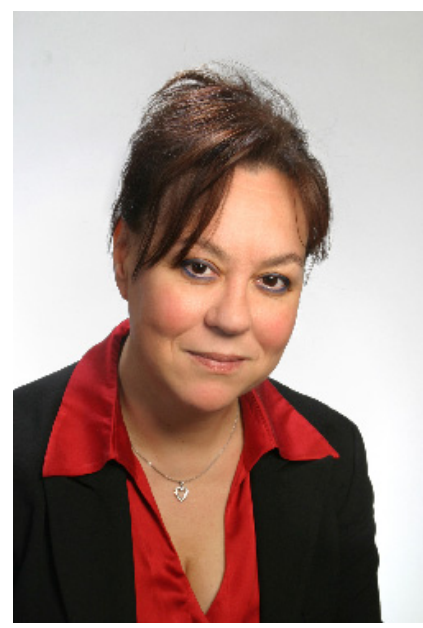

Antigoni Kotali was born in Thessaloniki, Greece and studied chemistry at the Aristotle University of Thessaloniki where she obtained her B.Sc. in 1981 and her Ph.D. in 1986 under the supervision of Professor V. P. Papageorgiou. Since 1981 she has been working in the University of Thessaloniki first as research assistant, then as a lecturer and later as an assistant professor. Her present position is an Associate Professor. In 1989-1990 she worked in Professor A R. Katritzky's group at the University of Florida, Gainesville, FL and later in 1994 in Professor S. W. Baldwin's group at Duke University, Durham, NC, on a sabbatical. Her scientific interests are mainly in organic synthesis, in particular, oxidations of nitrogen derivatives of carbonyl compounds and synthesis of molecules with biological activity. 